\title{
The Effect of Breast-Feeding on Proliferation by Infant Lymphocytes in Vitro
}

\author{
S. STEPHENS, M. K. BRENNER, S. W. DUFFY, P. K. LAKHANI, C. R. KENNEDY, AND \\ J. FARRANT \\ Divisions of Communicable Diseases, Immunological Medicine [M. K. B., J. F.] and Computing and Statistics \\ [S. W. D.], Clinical Research Centre, and Department of Paediatrics [P. K. L., C. R. K.], Northwick Park \\ Hospital, Watford Road, Harrow, Middlesex, England
}

\begin{abstract}
The effect of breast-feeding on the development of lymphocyte responsiveness in infants has been studied. Peripheral blood mononuclear cells from 15 breast- and 15 bottle-fed infants were obtained sequentially between 6 days and 9 months of age. A number of agents were used to stimulate the cells in vitro and the resulting proliferative responses were compared between the two feeding groups. A hanging drop microculture system using serum-free medium, enabled spontaneous proliferation and proliferative responses to several stimuli $(T$ and $B$ cell mitogens, allogeneic lymphocytes, and antigen) to be studied at a range of cell concentrations and days of culture. Significant age-related differences were found between the responses of cells from the two feeding groups. Spontaneous proliferation and proliferative responses to the $T$ cell mitogen phytohaemagglutinin and the antigen tetanus toxoid were significantly greater in the breast-fed group at the two earliest ages studied ( 6 days and $6 \mathrm{wk}$ ). Responses to mitogens which predominantly affect $B$ cells, such as pokeweed mitogen and Staphylococcus aureus (Cowan), were similar in both feeding groups at this age. In contrast, from 3 to 9 months of age, responses of cells from bottle-fed infants were significantly greater to all stimuli than responses from breast-fed infants. One possible explanation for the higher level of proliferation by cells from newborn breast-fed infants, is that these infants may absorb the cell-growth factors and lymphokines known to be present in human colostrum and milk. These factors may stimulate $T$ cells and/or their precursors in vivo. The subsequent greater responsiveness of peripheral blood mononuclear cells from the bottle-fed group at 3 to 9 months of age appears to be due to a higher level of antigenic stimulation in vivo in this group. This could result from the greater intake of cow milk proteins or from the absence of the passive protective effect of the antimicrobial components in human milk. (Pediatr Res 20: 227-231, 1986)
\end{abstract}

\section{Abbreviations}

FCS, fetal calf serum

MLR, mixed lymphocyte reaction

PBM, peripheral blood mononuclear cells

PHA, phytohemagglutinin

PWM, pokeweed mitogen

SAC, Staphylococcus aureus (strain Cowan I)

TT, tetanus toxoid

Received May 28, 1985: accepted October 31, 1985

Correspondence should be addressed to DR. S. Stephens, Division of Communicable Diseases, Clinical Research Centre, Watford Road, Harrow, Middlesex, HA1 3UJ, England.
Breast-fed infants have a lower incidence of infections than bottle-fed infants (1-3). This has been attributed to a passive protective role of antimicrobial compounds in human milk, such as secretory IgA, acting locally within the gut of the newborn infant (4-6). More recently, interest has developed in other factors in colostrum and milk, such as epidermal growth factor $(7,8)$, interferon $(9,10)$, and prostaglandins $(11,12)$, which can influence cell growth and differentiation in vitro. It is possible that these growth factors and lymphokines in milk may actively enhance the development of the immune system of the breastfed infant, although an in vivo role for milk lymphokines has not yet been demonstrated. To investigate whether these lymphokines might be having an effect in vivo on the immune system of the breast-fed infant, we have studied the development of immune responses in breast- and bottle-fed infants sequentially from 6 days to 9 months of age.

Mononuclear cell proliferation in vitro has frequently been used to assess immunocompetence in infants and adults (13). Many variables such as cell concentration, length of culture period, and mitogen concentration have been shown to have a profound effect on proliferative responses (14). However, only small numbers of cells can be obtained from infants so that assessment of immunocompetence has usually been made on estimations with a fixed level of each in vitro variable, which can be highly misleading $(15,16)$. In this study, we have used a Terasaki plate microculture system for mononuclear cells, which has enabled the effects of interacting variables such as cell concentration and period of culture to be assessed, using low total numbers of cells. Addition of serum to the culture medium can also complicate interpretation of results; batches of FCS which support cell growth are often mitogenic and may contain growth factors (17). We have therefore used a serum-free medium to culture PBM cells from healthy full-term breast- and bottle-fed infants, in order to determine the effects of feeding group on the development of spontaneous (background) proliferation and proliferative responses to mitogens and allogeneic lymphocytes. The results indicate contrasting age-related differences in the responses of cells from the two feeding groups. Breast-feeding has a stimulating effect on cell proliferation in the early neonatal period, but in the older infants, breast-feeding reduces the proliferative responses to a wide range of stimuli.

\section{MATERIALS AND METHODS}

Subjects and samples. Thirty healthy full-term infants, born at Northwick Park Hospital, were selected with full parental consent. The choice of feeding group was left entirely to the families. Fifteen infants were fed on cow milk formula (SMA Gold Cap) from birth. Twelve infants were exclusively breast-fed for at least 3 months and fully weaned beyond 7 months of age. Three breast-fed infants were weaned early (before 2 months). All 
infants receiving one or two doses of triple vaccine (containing 60 IU adsorbed tetanus toxoid) between 3 and 9 months of age. Heparinized blood (1-5 ml blood with $20 \mathrm{U}$ heparin/ml) was collected by venepuncture at 6 days, $6 \mathrm{wk}, 3,6$, and 9 months of age.

Preparation of mitogen from $S A C$. SAC was obtained from the National Collection of Type Cultures, Colindale, London, England (NCTC 8503). Organisms were cultured overnight at $37^{\circ} \mathrm{C}$ in brain heart infusion broth (Oxoid) containing $1 \%$ proteose peptone. Mitogen was prepared according to the method of Banck and Forsgren (18). Killed organisms were resuspended $1: 10 \mathrm{v} / \mathrm{v}$ in RPMI 1640 with bicarbonate $(2 \mathrm{~g} / \mathrm{l}$, pH 7.4, Flow Laboratories) and stored at $-70^{\circ} \mathrm{C}$.

Stimulator cells for mixed lymphocyte reaction. Stimulator cells used were Cla-4 Epstein-Barr virus induced B cell line, tissue type A2, A29; B12, B27; Cwl; Bw4; DR7, DR3. Cells were grown in medium [ $50 \%$ RPMI 1640 with $\mathrm{NaHCO}_{3}$ and $50 \%$ Eagle's minimal essential medium (Flow)] containing 10\% FCS. Cultured cells were centrifuged and resuspended in RPMI 1640 with Hepes $(20 \mathrm{mM}, \mathrm{pH} 7.2)$ to $20 \times 10^{6}$ cells $/ \mathrm{ml}$. Mitomycin-C (50 $\mu \mathrm{g} / \mathrm{ml}$ cell suspension) was added, cells were incubated for 30 min at $37^{\circ} \mathrm{C}$, washed three times in RPMI 1640 with Hepes and resuspended at $1 \times 10^{8}$ cells $/ \mathrm{ml}$ in RPMI with Eagle's containing $5 \%$ dimethyl sulphoxide. Cells were then distributed in $100 \mu 1$ volumes in cooled cryotubes (Nunc), frozen in a glycerol bath for $30 \mathrm{~min}$ at $-30^{\circ} \mathrm{C}$ and rapidly transfered to liquid nitrogen. Mitomycin- $C$ treated cells were thawed rapidly immediately before use and resuspended at $4 \times 10^{6}$ cells $/ \mathrm{ml}$ in Iscove's Modified Dulbecco's serum-free medium (Flow) containing penicillin $(100 \mathrm{IU} / \mathrm{ml})$, streptomycin $(100 \mu \mathrm{g} / \mathrm{ml})$, and L-glutamine ( $2 \mathrm{mM})$. Viability, assessed by trypan blue dye exclusion, was estimated at $60-70 \%$. Duplicate control wells were set up with each experiment to confirm that these mitomycin- $C$ treated cells did not proliferate when recultured in the MLR.

Microculture system. The Terasaki plate microculture system described by O'Brien et al. (19) was used. Peripheral blood mononuclear cells were separated on a Ficoll-Paque gradient (Pharmacia), washed twice and resuspended in Iscove's Modified Dulbecco's serum-free medium with $\mathrm{NaHCO}_{3}(3.2 \mathrm{~g} / \mathrm{liter}$, pH 7.4), antibiotics, and L-glutamine (see above). For unstimulated cultures and mitogen or antigen stimulated cultures, cells were dispensed in $20 \mu \mathrm{l}$ volumes using Hamilton repeat dipensing syringes, into Terasaki plates (Nunc) at $1,2,4$, and $8 \times 10^{6}$ cells/ ml. Preliminary titration experiments indicated that the optimal doses of stimulants (added in $1 \mu \mathrm{l}$ volumes to give final concentrations) were as follows: PHA (Wellcome Laboratories) $1 \mu \mathrm{g} /$ $\mathrm{ml}$; PWM (Sigma) $1 \mu \mathrm{g} / \mathrm{ml}$; SAC 1/2000; TT (kindly donated by Dr. R. O. Thomson, Wellcome Laboratories, Kent, England)
$2 \mathrm{ng} / \mathrm{ml}$. For MLR cultures, cells were dispensed in $10 \mu \mathrm{l}$ volumes at double concentration and $10 \mu \mathrm{l}$ of mitomycin-C treated Cla4 stimulator cells were added to give a final concentration of 2 $\times 10^{6}$ stimulator cells $/ \mathrm{ml}$. Separate plates were set up for each day of harvest. Plates were inverted and incubated in boxes containing $0.85 \%$ saline in a humid incubator with $5 \% \mathrm{CO}_{2}$ at $37^{\circ} \mathrm{C}$. All cultures were set up in duplicate.

Harvesting cell cultures. Cells were harvested on days 3 to 5 of culture as described previously $(14,19)$. Briefly, cultures were pulsed for $2 \mathrm{~h}$ at $37^{\circ} \mathrm{C}$ with $1 \mu \mathrm{l}$ of $\left[{ }^{3} \mathrm{H}\right]$ methylthymidine (Amersham Radiochemicals Ltd.) at $2 \mathrm{Ci} / \mathrm{mmol}$ to give a final concentration of $1 \mu \mathrm{g} / \mathrm{ml}$ thymidine $(0.16 \mu \mathrm{Ci} /$ well $)$. Cell pellets were harvested on to glass-fiber filters on a Terasaki plate harvester, washed with saline and $5 \% \mathrm{w} / \mathrm{v}$ trichloroacetic acid, and dried with methanol. Discs were transferred to plastic scintillation vials with $0.5 \mathrm{ml}$ scintillant (NE 260, Nuclear Enterprises), counted on a Wallac LKB scintillation counter and results expressed as counts per minute.

Statistics. The statistical analysis was similar to that employed by Harrison et al. (20). From a possible 150 samples ( 30 infants bled on five occasions), between 138 (spontaneous proliferation) and 122 (MLR) were cultured at a minimum of three cell concentrations $\left(1,2\right.$, and $4 \times 10^{6}$ cells $\left./ \mathrm{ml}\right)$ and harvested on 2 days of culture ( 3 and 5 ). In addition, $35 \%$ of samples were cultured at $8 \times 10^{6}$ cells $/ \mathrm{ml}$ and $45 \%$ were harvested on day 4 of culture. Results were log-transformed to normalize the distribution and geometric means of duplicate cultures were calculated. Analysis of variance was performed on the data from each stimulant to determine differences between feeding groups and interactions of feeding group with age, culture period, and cell concentration. Allowance was made for the fact that both between-infant and within-infant sources of variation were present (21). Because of the lack of balance with respect to cell concentration, data were further divided into cell concentrations and the analysis of variance reapplied. Where individual comparisons between groups were required at specific ages, days of culture, or cell concentrations, Bonferroni $t$ tests were performed (22). These take into account the circumstance of multiple tests and so are more conservative than pooled $t$ tests. For the purposes of these $t$ tests, the appropriate variance estimates, derived from the analysis of variance procedure, were used. Where confidence intervals $(95 \%)$ were constructed, these incorporated variability both between and within infants.

\section{RESULTS}

General observations on the kinetics of proliferation by cells from infants. In Table 1 the geometric means of the amount of

Table 1. Effect of length of culture period on proliferation by infant PBM cells*

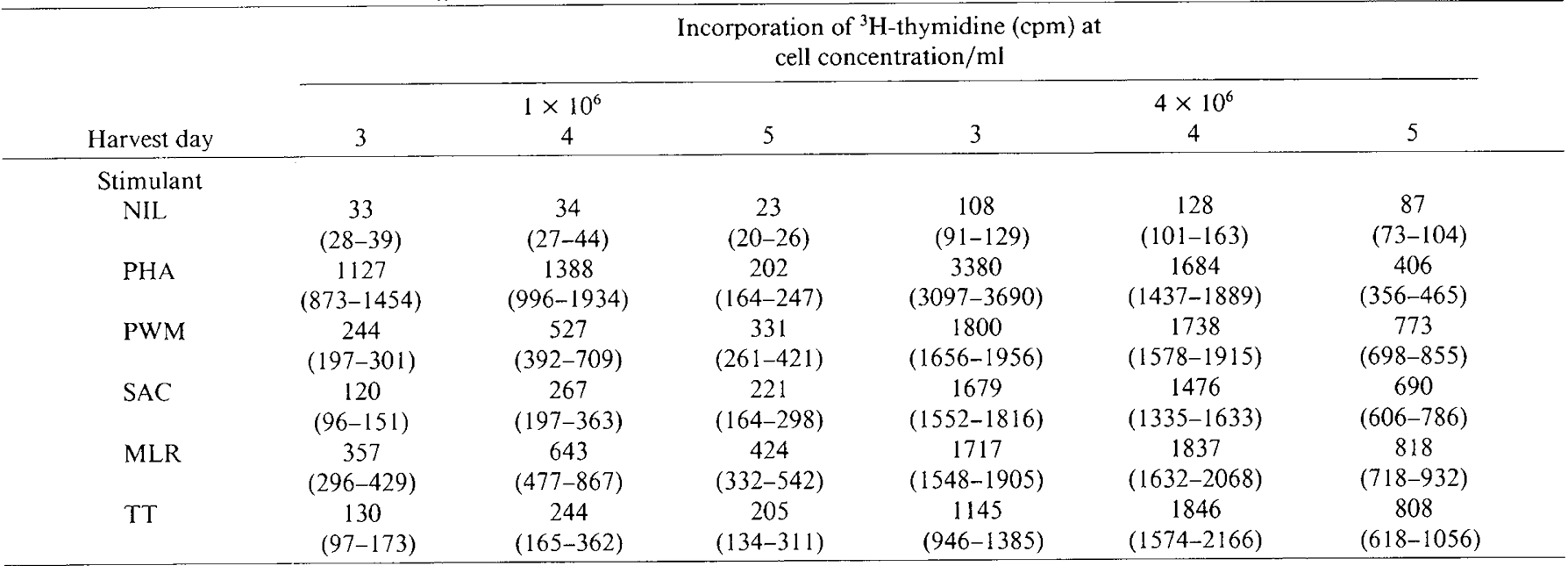

\footnotetext{
* Values are geometric means (and $95 \%$ confidence intervals) of duplicate cultures of samples from 30 infants on five sampling occasions. For
} days 3 and $5, n \leq 150$; for day $4, n \leq 65$. 
$\left[{ }^{3} \mathrm{H}\right]$ methylthymidine incorporated $(\mathrm{cpm})$ for the 30 breast- and bottle-fed infants, averaged over the five occasions, are shown for each stimulant at two cell concentrations for harvest days 3 to 5. Each mean therefore represents up to 150 samples. Maximal responses occurred on day 3 (or earlier) for PHA and on days 3 and 4 for other stimuli, although at lower cell concentrations maximal responses occurred later in the culture period. There was a significant effect of cell concentration on proliferation (shown averaged over all days of culture) (Table 2). For spontaneous proliferation (without added mitogens or antigen) maximal responses occurred at the highest cell concentration studied $\left(8 \times 10^{6}\right.$ cells $\left./ \mathrm{ml}\right)$ but for responses to all stimuli maximal responses occurred at $4 \times 10^{6}$ cells $/ \mathrm{ml}$; further increases in cell concentration resulted in lower proliferative responses.

Differences between proliferation by cells from breast- and bottle-fed infants: spontaneous (background) proliferation. There was a significant interaction of the effects of feeding group and age, that is the change in proliferation with age was significantly different for the two feeding groups $(p=0.012)$. This difference

Table 2. Effect of cell concentration on proliferation by infant PBM cells*

Incorporation of ${ }^{3} \mathrm{H}$-thymidine (cpm) at cell concentration $/ \mathrm{ml} \times 10^{6}$

\begin{tabular}{ccccc} 
& 1 & 2 & 4 & 8 \\
\hline Stimulant & & & & \\
NIL & 29 & 49 & 102 & 158 \\
& $(26-32)$ & $(44-55)$ & $(92-115)$ & $(137-183)$ \\
PHA & 574 & 1151 & 1245 & 1132 \\
& $(483-684)$ & $(1003-1321)$ & $(1097-1413)$ & $(964-1328)$ \\
PWM & 318 & 949 & 1269 & 952 \\
& $(275-368)$ & $(870-1034)$ & $(1181-1364)$ & $(831-1092)$ \\
SAC & 179 & 853 & 1143 & 804 \\
& $(151-211)$ & $(771-944)$ & $(1054-1239)$ & $(676-956)$ \\
MLR & 428 & 1038 & 1296 & 1049 \\
& $(373-491)$ & $(951-1133)$ & $(1193-1409)$ & $(869-1266)$ \\
TT & 181 & 790 & 1152 & Not tested \\
& $(145-224)$ & $(675-925)$ & $(1005-1319)$ & \\
\hline
\end{tabular}

* Values are geometric means (and 95\% confidence intervals) of duplicate cultures from 30 infants sampled on five occasions and harvested on 3 days of culture. For 1,2 , and $4 \times 10^{6}$ cells $/ \mathrm{ml}, n \leq 340$; for $8 \times 10^{6}$ cells $/ \mathrm{ml}, n \leq 120$.

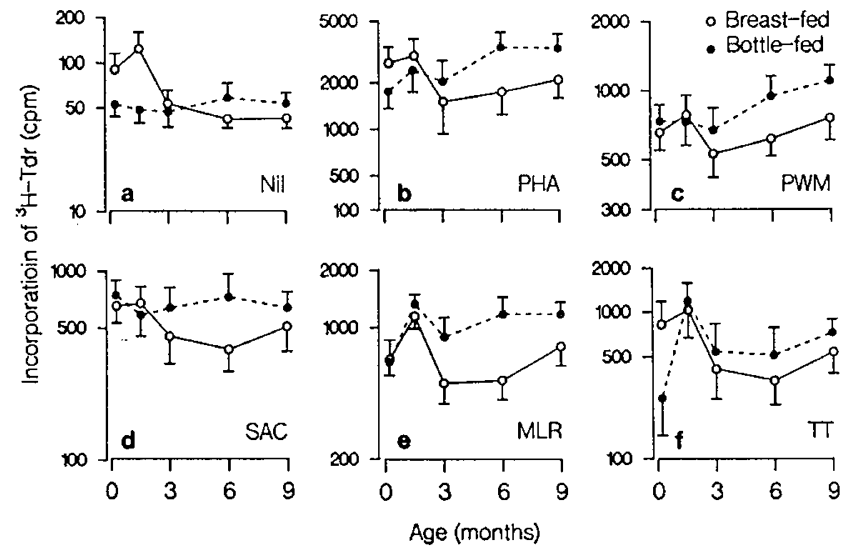

Fig. 1. Spontaneous proliferation (Nil) and proliferative responses of PBM cells from breast- and bottle-fed infants to mitogens (PHA, PWM, and SAC), allogeneic lymphocytes (MLR) and antigen (TT). Figures are expressed as geometric means ( $\pm 95 \%$ confidence intervals) of ${ }^{3} \mathrm{H}$ thymidine incorporated by cells from 15 infants in each feeding group; cells were cultured in duplicate at a minimum of three cell concentrations $\left(1,2\right.$, and $4 \times 10^{6}$ cells $\left./ \mathrm{ml}\right)$. PHA results are for day 3 of culture only: for all other stimuli results are means from days 3,4 , and 5 of culture.

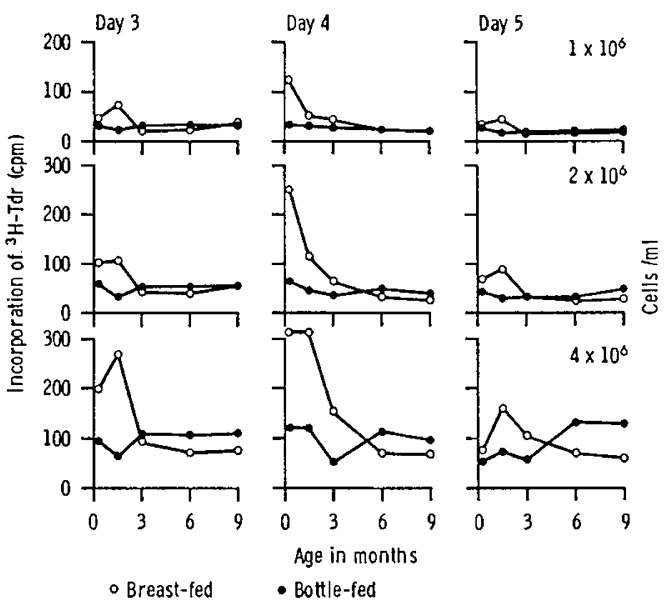

Fig. 2. Spontaneous proliferation by PBM cells from breast- and bottle-fed infants. Results are expressed as geometric means of ${ }^{3} \mathrm{H}$ thymidine incorporated by cells from 15 infants in each feeding group.

is illustrated (with results averaged over all harvest days and cell concentrations) in Figure $1 a$. At 6 days and $6 \mathrm{wk}$ of age, cells from breast-fed infants incorporated more thymidine than cells from bottle-fed infants. This high rate of spontaneous proliferation for newborn breast-fed infants, diminished between 6 wk and 3 months. By 6 and 9 months, cells from the bottle-fed infants showed slightly higher rates of proliferation. A detailed analysis of this interaction of feeding group with age (Fig. 2) indicated that it occurred on all days of culture and at all cell concentrations, but was most significant at $4 \times 10^{6}$ cells $/ \mathrm{ml}(p$ $=0.0013$ ) and for the 2 peak days of culture (days 3 and 4).

Proliferative responses to the $T$ cell mitogen $P H A$. When proliferative responses were examined on the peak day of culture for PHA (day 3, see Table 1), there was a highly significant interaction of feeding group with age (Fig. $1 b, p=0.007$ ). As with spontaneous proliferation, proliferative responses to PHA were greater in the breast-fed group during the early neonatal period, but by 3 months the responses were greater in the bottlefed group (at all cell concentrations and days of culture) and this difference was maintained beyond 9 months of age. The interaction of the effects of feeding group with age (by analysis of variance) did not quite reach a $5 \%$ level of significance when results were averaged over all cell concentrations and days of culture $\left(p^{\prime}=0.058\right)$ although there was a significantly greater response by cells from bottle-fed infants when tested on each individual occasion from 3 to 9 months ( $t$ test, $p<0.05$ ).

Proliferative responses to $B$ cell mitogens $P W M$ and $S A C$. The pattern of proliferative responses of cells to PWM and SAC (averaged over all cell concentrations and culture days) was similar, although the magnitude of responses to SAC were lower (Fig. $1 c$ and $d$ ). At 6 days and 6 wk of age, there were no detectable differences in the responses of cells from breast-fed and bottle-fed infants. However, by 3 months the responses of cells from bottle-fed infants were greater than those from breastfed infants, at each cell concentration and day of culture, and this difference between feeding groups were significant at 6 and 9 months of age for both mitogens ( $t$ test: PWM, $p<0.05$; SAC, $p<0.01$ ).

Mixed lymphocyte reaction. The responses to allogeneic lymphocytes indicated the largest differences between the groups, with a significantly greater overall group mean (averaged over all cell concentrations, days of culture, and ages) for the bottle-fed infants $(p=0.004)$. The interaction of feeding group with age was significant $(p=0.029)$ and is illustrated in Figure $1 e$. At 6 days and $6 \mathrm{wk}$ of age, although there was no difference in the overall response (averaged over all days of culture), the peak responses of cells from breast-fed infants occurred earlier in the culture period than those from the bottle-fed group (results not shown). From 3 to 9 months of age there were significantly 
greater responses by cells from bottle-fed infants at all cell concentrations and on all days of culture (Fig. $1 e$ ).

Proliferative responses to the antigen TT. Fewer samples (54/ 150) were cultured with TT at the minimum of three cell concentrations and 2 days of harvest. The pattern of response was similar to that in response to PHA (Fig. 1f). There was a significantly greater response of cells from breast-fed infants during the early neonatal period ( $t$ test, $p<0.05$ at 6 days). Maximal proliferation by cells from both groups was at $6 \mathrm{wk}$ of age and from 3 to 9 months there were lower responses for the breast-fed group. This pattern was similar for all cell concentrations and days of culture. However, because of the low numbers of samples, no significant interactions were detected by the analysis of variance.

\section{DISCUSSION}

Comparison of the in vitro proliferation by cells from breastand bottle-fed infants indicated significant differences between the two feeding groups for spontaneous (background) proliferation and for proliferative responses to all stimuli used. These differences were age-dependent and fell into two main categories; those which occurred in newborn infants (6 days and $6 \mathrm{wk}$ ) and those which occurred in older infants ( 3 to 9 months). Cells from newborn breast-fed infants showed significantly greater rates of spontaneous proliferation and were more responsive to PHA and TT than cells from bottle-fed infants (at all cell concentrations and on all days of culture). Responses of cells to allogeneic lymphocytes also occurred more rapidly in the breast-fed group at this age. Previous work, using adult cells, has indicated that cells which proliferate spontaneously may be a population of $\mathrm{T}$ cell precursors (23), whereas PHA and allogeneic lymphocytes have been shown to stimulate mature $\mathrm{T}$ cells rather than $\mathrm{B}$ cells $(24,25)$. Thus, the greater proliferation of cells from the breastfed group at 6 days and $6 \mathrm{wk}$ of age, suggests that $T$ cells (or their precursors) may be in a greater state of activation in vivo in breast-fed infants. TT antigen has also been shown to stimulate proliferation of $\mathrm{T}$ cells rather than $\mathrm{B}$ cells from immune adult donors (26). Since the newborn breast-fed infants in this study were not vaccinated either the proliferation was due to a primary antigen specific response (which is unlikely due to the magnitude of the responses obtained) or the responses were antigen nonspecific. Leiken and Oppenheim (27) also found high proliferative responses to TT by cord blood lymphocytes from a few infants which they were unable to explain. This response may represent a mitogenic effect of the TT preparation: TT certainly induces polyclonal IgM secretion by cells from these unimmunized infants (Stephens, unpublished results). In contrast to the clear differences between breast- and bottle-fed infants when stimuli that predominantly activate $\mathrm{T}$ cells are examined, proliferative responses to mitogens affecting $B$ cells (PWM and SAC) showed no differences between the feeding groups during this early neonatal period, at any cell concentration or day of culture. This suggests that $\mathrm{B}$ cell responses were comparable in the two groups at this time. This finding is supported by the similar serum immunoglobulin levels observed in these infants (28). It is not clear why cells from breast-fed infants should demonstrate enhanced spontaneous proliferation and proliferative responses to $\mathrm{T}$ cell mitogens in the early neonatal period, compared with bottle-fed infants. A number of factors that are capable of stimulating lymphocytes in vitro have been shown to be present in human colostrum and milk. These factors include epidermal growth factor $(7,8)$, which in addition to stimulating the growth of epithelial cells in vitro, has also been shown to enhance antigen-driven T-cell proliferation (29). Colostral and milk leucocytes cultured in vitro secrete interferon $(9,10,30)$ and prostaglandins $(11,12)$ which are also capable of modulating lymphoid cell proliferation. Additional factors in colostrum and milk (possibly interleukin-1, B cell growth or differentiation factors) can enhance $\mathrm{B}$ cell proliferation and differentiation in vitro (31-
33 ) and a factor from the milk of atopic mothers can stimulate IgE secretion (34). Whether these growth factors and lymphokines are absorbed by the gut of the breast-fed infant and stimulate the maturation of lymphocytes in vivo is not known, but the enhanced in vitro responsiveness of $\mathrm{T}$ cells from newborn breast-fed infants in this study suggests that at least some of these factors may be active in vivo.

By 3 to 9 months of age, spontaneous proliferation and proliferative responses to all stimuli (PHA, PWM, SAC, MLR, and TT) were significantly greater in the bottle-fed group. This difference was apparent at all cell concentrations and on all days of culture but was proportionally greatest on the day of culture at which proliferation was highest. In a study of allergy, Juto et al. (35) also found a greater responsiveness of cells from bottle-fed infants to PHA at 3 to 6 months. This reversal of responsiveness in the older infants studied suggested that all types of PBM cells (non- $\mathrm{T} /$ non- $\mathrm{B}, \mathrm{T}$ and $\mathrm{B}$ cells) were receiving greater stimulation in vivo in the bottle-fed infants. This could be the result of a combination of effects. First, by this age there may be a reduced intake of lymphokines and growth factors from milk in the breast-fed infants. Pittard and Bill (32) were able to detect the IgA stimulatory factor in supernatants only from colostral and early milk cell cultures but not from mature milk cell cultures. Second, factors in human milk such as secretory component (36) and lipid (35) have been shown to inhibit lymphocyte responses in vitro, and these factors may begin to have a role in vivo at this age. However, a more likely explanation is that bottle-fed infants have a greater uptake of macromolecules from the gut than breast-fed infants, as the lack of protective antibodies from human milk in the bottle-fed infants allows increased absorption of potentially antigenic macromolecules from gut bacteria (37) and cow milk proteins (38). Certainly, the serum antibody responses of these bottle-fed infants to components of the normal gut flora are significantly greater than those of the breast-fed infants at this time (28) indicating greater exposure of the systemic immune system to antigens encountered in the gut. Endotoxin and lipopolysaccharide from normal gut flora have been shown to have a profound stimulatory effect on the immune system of animals and man $(37,39-41)$. The greater responsiveness of cells from bottle-fed infants at 3 to 9 months of age may thus be due to increased stimulation of the systemic immune system by macromolecules absorbed from the gut.

The present data show clear differences in the proliferative responses of cells from breast- and bottle-fed infants. Active stimulation and passive protection by human milk appear to have antagonistic effects on the development of immune responses in infants. An early enhancing effect, perhaps due to absorption of soluble growth factors or lymphokines from colostrum and milk, may be important during the immediate neonatal period when the immune system is particularly immature, yet has to cope with the sudden exposure to environmental antigens. From 3 months of age, the lower proliferative responses of lymphocytes from breast-fed infants may result from the passive protective action of secretory $\mathrm{IgA}$ and other antimicrobial components present in human colostrum and milk, which shield the immune system of the breast-fed infant from stimulation by food antigens, microorganisms, and other potentially antigenic or mitogenic molecules present in the gut of the infant.

This study therefore gives further evidence for the benefits of breast-feeding, indicating that in addition to passive protection against organisms which are potentially pathogenic, breast-feeding acts as a modulator of immunological development. This may be particularly valuable in early infancy when the child is most susceptible to infection.

Acknowledgments. The authors thank Dr. H. B. Valman for allowing access to infants born at Northwick Park Hospital. This study was approved by the Ethical Committee of Northwick Park Hospital (E.C.772). 


\section{REFERENCES}

1. Grulee CG, Sanford HN, Herron PH 1934 Breast and artificial feeding, influence on morbidity and mortality of twenty thousand infants. JAMA 103:735-738

2. Robinson M 1951 Infant morbidity and mortality. A study of 3266 infants. Lancet 1:788-794

3. Cunningham AS 1979 Morbidity in breast-fed and artifically-fed infants. II. J Pediatr 95:685-689

4. Hanson LA, Winberg J 1972 Breast milk and defence against infection in the newborn. Arch Dis Child 47:845-848

5. Goldman AS, Smith CW 1973 Host resistance factors in human milk. J Pediatr 82:1082-1090

6. Welsh JK, May JT 1979 Anti-infective properties of breast milk. J Pediatr 94:1-9

7. Klagsbrun M 1978 Human milk stimulates DNA synthesis and cellular proliferation in cultured fibroblasts. Proc Natl Acad Sci USA 75:5057-5061

8. Carpenter $G 1980$ Epidermal growth factor is a major growth-promoting agent in human milk. Science 210:198-199

9. Emodi G, Just M 1974 Interferon production by lymphocytes in human milk. Scand J Immunol 3:157-160

10. Lawton JWM. Shortridge KF, Wong RCL, Ng MH 1979 Interferon synthesis by human colostral leucocytes. Arch Dis Child 54:127-130

11. Lucas A. Mitchell MD 1980 Prostaglandins in human milk. Arch Dis Child 55:950-952

12. Blau H, Passwell JH, Levanon M, Davidson J, Cohen F, Ramot B 1983 Studies on human milk macrophages: effect of activation on phagocytosis, and secretion of prostaglandin E2 and lysozyme. Pediatr Res 17:241-245

13. Chandra RK, Cooper MD, Hitzig WH, Rosen FS, Seligman M, Soothill JF, Terry RJ 1978 Immunodeficiency. Report of a WHO Scientific Group. Technical Report Series 630:1-80

14. Farrant J, Clark JC, Lee H, Knight SC, O'Brien J 1980 Conditions for measuring DNA synthesis in PHA stimulated human lymphocytes in $20 \mu$ hanging drops with various cell concentrations and periods of culture. $J$ Immunol Methods 33:301-312

15. Stites DP, Wybran J, Carr MC, Fudenberg HH 1972 Development of cellular immunocompetence in man. In: Ontogeny of Acquired Immunity. Ciba Foundation Symposium, Amsterdam, Elsevier, pp 113-128

16. Wara DW, Barrett DJ 1979 Cell-mediated immunity in the newborn: Clinical aspects. Pediatrics $64: 822 \mathrm{~s}-826 \mathrm{~s}$

17. Farrant J, Newton CA, North ME, Weyman C, Brenner MK 1984 Production of antibody by human $\mathrm{B}$ cells under serum-free conditions. $\mathrm{J}$ Immunol Methods 68:25-34

18. Banck G, Forsgren A 1978 Many bacterial species are mitogenic for human blood B lymphocytes. Scand J Immunol 8:347-354

19. O'Brien J. Knight SC, Quick NA, Moore EH, Platt AS 1979 A simple technique for harvesting lymphocytes cultured in Terasaki plates. $J$ Immunol Methods 27:219-223

20. Harrison RA, Lee H, Farrant J 1981 Variability of lymphocyte response to PHA in patients with operable breast carcinoma: effect of cell concentration, PHA dose, serum and period of cultivation. Clin Oncol 7:205-212

21. Winer BJ 1971 Statistical principles in experimental design. McGraw-Hill, Kogakusha, Tokyo, pp 514-559

22. Gill JL 1978 Completely ramdomised designs and analysis of variance. In
Design and Analysis of Experiments, Vol 1. Iowa State University Press, Ames, IA, pp 176-177

23. Treves AJ, Barak V, Fuks Z 1980 Characterisation of human lymphocytes which proliferate "spontaneously" in vitro. Eur J Immunol 10:883-887

24. Rich RR, Pierce CW 1973 Biological expressions of lymphocyte activation. I. Effects of phytomitogens on antibody synthesis in vitro. J Exp Med 137:205223

25. Kuntz MM, Innes JB, Weksler ME 1976 Lymphocyte transformation induced by autologous cells. IV. Human T-lymphocyte proliferation induced by autologous or allogeneic non-T lymphocytes. J Exp Med 143:1042-1054

26. Geha RS, Merler E 1974 Response of human thymus-derived (T) and nonthymus-derived (B) lymphocytes to mitogenic stimulation in vitro. Eur $\mathrm{J}$ Immunol 4:193-199

27. Leiken S, Oppenheim JJ 1970 Differences in transformation of adult and newborn lymphocytes stimulated by antigen, antibody and antigen-antibody complexes. Cell Immunol 1:468-475

28. Stephens S, Kennedy CR, Lakhani PK, Brenner MK 1984 In vivo immune responses of breast- and bottle-fed infants to tetanus toxoid antigen and to normal gut flora. Acta Paediatr Scand 73:426-432

29. Acres RB, Lamb JR, Feldman M 1985 Effect of platelet-derived growth factor and epidermal growth factor on antigen-induced proliferation of human $T$ cell lines. Immunology 54:9-16

30. Keller MA, Kidd RM, Bryson YJ, Turner JL, Carter J 1981 Lymphokine production by human milk lymphocytes. Infect Immun 32:632-636

31. Pittard III WB, Bill K 1979a Immunoregulation by breast milk cells. Cell Immunol 42:437-441

32. Pittard III WB, Bill K $1979 \mathrm{~b}$ Differentiation of cord blood lymphocytes into IgA-producing cells in response to breast milk stimulatory factor. Clin Immunol Immunopathol 13:430-434

33. Juto P 1985 Human milk stimulates B cell function. Arch Dis Child 60:610613

34. Allardyce RA, Wilson A 1984 Breast milk supernatants from atopic donors stimulate cord blood IgE secretion in vitro. Clin Allergy 14:259-267

35. Juto P, Möller C, Engberg S, Björkstén B 1982 Influence of type of feeding on lymphocyte function and development of infantile allergy. Clin Allergy 12:409-416

36. Crago SS, Kulhavy R, Prince SJ, Mestecky J 1981 Inhibition of the pokeweed mitogen-induced response of normal peripheral blood lymphocytes by humoral components of colostrum. Clin Exp Immunol 45:386-392

37. Tlaskalova-Hogenova H, Sterzl J, Stepankova R, Diadac V, Vetvicka V Rossman P, Mandel L, Rejnak J 1983 Development of immunological capacity under germ-free and conventional conditions. Ann NY Acad Sci 409:96-113

38. Fällström SP, Ahlstedt S, Carlsson B, Wettergren B, Hanson LA 1984 Influence of breast-feeding on the development of cow's milk protein antibodies and the IgE level. Int Arch Allergy Appl Immunol 75:87-91

39. Lagrange PH, Mackaness GB, Miller TE, Pardon P 1975 Effects of bacterial lipopolysaccharide on the immune induction and expression of cell mediated immunity. I. Depression of the afferent arc. J Immunol 114:442-446

40. Cebra JJ, Gearhart PJ, Halsey JF, Hurwitz JL, Shahin RD 1980 Role of environmental antigens in the ontogeny of the secretory immune response. J Reticuloendothel Soc 28:61s-71s

41. Rethy L 1983 Immunomodulant activity of endotoxins in man. Ann Immunol Hung 23:15-53 